\section{Medical Toxicology: A Synopsis and Study Guide} Seth Schonwald

Philadelphia, PA: Lippincott Williams \& Wilkins, 2001

US $\$ 99.95,893$ pages, softcover

In its preface, this book purports to update, summarize, and edit Ellenhorn's Medical Toxicology text, which has been a primary medical toxicology reference for several years. At a svelte 862 pages of text, this paperback does an excellent job of providing the pertinent facts on a wide array of toxins, both natural and manufactured. However, it is not, nor should it be expected to be, a replacement for the $2000+$ page tome it is based upon.

The text crosses international borders with antidotes used in other countries and provides their trade names for easy reference. All the usual topical areas as well as intoxication with veterinary medications are included. A particular strength of the text is its inclusion of well-known complications and reactions to be expected from the use of antidotes (eg, expecting fever on the second and third dose of dimercaprol treatment in children). Intrachapter questions test knowledge and comprehension of sections and provide instant feedback on areas needing further review, and nice examples calculating drug concentrations and predicting blood levels after ingestions are given using pharmacokinetic formulas.

The food toxicology section, with several pages devoted to food-borne bacterial and parasitic pathogens, although excellent and of interest to those with a wilderness medicine bent, seems more suited to a microbiology text than to a toxicology text.

Of special interest for Wilderness Environ Med readers, Part V Natural Toxins has chapters covering reptiles, amphibians, marine toxicology, mammals, arthropods, herbal medicines, volatile oils, plant dermatitis, beans, houseplants, food plants, wild plants, mushrooms, and mycotoxins. Although many items are covered, the discussion is brief at best and irrelevant at worst. There are no charts, graphs, illustrations, or pictures of any kind, thereby making the book tiring to the eye and a challenge to continue reading.

This book would be recommended for someone wanting a no-frills review and self-assessment of medical toxicology. It is not a reference text.

Charles F. Dryden, Jr, MD Carrollton, TX, USA

\author{
Bear Attacks: Their Causes and Avoidance, \\ revised edition \\ Stephen Herrero \\ Guilford, CT: The Lyons Press, 2002 \\ (original edition 1985) \\ US $\$ 16.95,282$ pages, softcover
}

Bear Attacks: Their Causes and Avoidance is the ultimate reference book on North American brown and black bears. Unlike any other book on the market about bear attacks (and there are many!), this text is based on science rather than sensational accounts and folklore. If you are looking to be scared out of your sleeping bag and deluged with gory details of bear attacks, read one of the other books. But if you want to learn about bears, why they act as they do, and how humans should behave in the wilderness, then this book is not only worth reading, but it is very likely to give you the tools you need to save your life in a bear encounter.

Herrero's mission, which he achieves grandly, is to empower people to decrease the likelihood of encounters with bears by teaching bear biology and ecology — not only to protect people but to conserve bears. The author's lifelong experience, both personal and professional, gives him unparalleled expertise in the behavior of bears, and many of the studies he references are from his own original research as Professor of Biology at the University of Calgary. He teaches us how to recognize bears (different types of bears have vastly different responses to the same situation), where bears are likely to be (based on season of year and foods available), and how to recognize if a bear has been nearby (and how recently). Because of his years of research and interviews of bear-attack victims, he has compiled a very useful and reproducible set of suggestions for people who encounter a wild bear. From how to best avoid an encounter to how to behave when under attack by a bear, Herrero's observations have educated thousands and surely have saved many lives.

The text has plenty of maps, line drawings, and photographs (all black and white) to illustrate everything from the range of the grizzly bear to the differences between black and brown bear tracks to the posture one should assume in case of attack. It is disappointing that many of the photos and drawings are fuzzy or overexposed, obviously rephotographed from the original text. In many cases, the quality of the art or photo is much clearer and of better quality in the 1985 edition. Shame on the publisher for cutting corners and for advertising this revised edition as "thoroughly revised and updated." Aside from the new introduction and the addition of a discussion on cayenne pepper spray, trail design, and perimeter monitoring systems, most of the text is 
unchanged and identical to the 1985 version. As the author says in his introduction, bears' behavior has not changed much in the past 20 years.

Marketing ploy? Perhaps, but I will let it slide. Even if you buy the revised edition and realize that you have essentially reread most of the 1985 version, you will still be entertained and informed. People who work or recreate in bear country probably need a refresher every 15 years or so anyway. The information is accurate, and no one has done a better job in the last 17 years. Herrero's Bear Attacks remains the ultimate resource on North American bears for both the highly educated bear biologist and the lay person alike.

Luanne Freer, MD, FACEP Bozeman, MT, USA

\section{The Bears of Yellowstone, 3rd edition}

Paul Schullery

Worland, WY: High Plains Publishing Company, Inc. 1992

US \$15.00, 318 pages, softcover

There are perhaps no wild animals that are as famous as the bears of Yellowstone National Park. They have been the subjects of everything from scientific studies and documentaries to fictional stories and a popular cartoon television show. Although their history begins long before the establishment of Yellowstone National Park in 1872, the most dramatic changes have occurred since that time. This is due in large part to human intervention.

In the early days of Yellowstone National Park, bears were hunted legally for sport. In the first half of the 20th century, in response to decreasing numbers of park visitors, the National Park Service fed the animals garbage as part of a popular tourist attraction. Only through the work of dedicated naturalists and scientists are we coming to better understand these animals and what needs to be done to protect them and ensure their survival. It is essential to understand the history of these animals in Yellowstone National Park to fully appreciate the situation as it exists today.

The Bears of Yellowstone is divided into three sections. The first, "The Wild Bears of Yellowstone," is dedicated to the natural history of the bears. The section begins with a general description of the black bear. There are chapters discussing food habits, mating and cub growth, denning, and lifestyle. This is followed by a section of identically named chapters pertaining to the grizzly bear. In this section, the reader is provided a concise yet informative background to these animals.

The second section of the text, "Of Bears and Men," discusses the relationship of these animals with humans and how the relationship has changed during the period from the establishment of Yellowstone as a National Park in 1872 to the early 1990s. This section begins to tackle the difficult issue of bear management in Yellowstone. There has been much controversy concerning the bears as wild animals and as popular tourist attractions. There needs to be a balance between the best interest of the bears, which is served by their remaining wild with minimal human intrusion, and the reality that many visitors feel their trip to Yellowstone is incomplete without seeing a bear. The book traces this controversy from its origins to the present day. The history of the bears of Yellowstone is not unlike that of many other natural resources. Once looked upon as plentiful and at times a nuisance, the bears are now recognized as a threatened natural treasure whose very survival is uncertain as a result of human intervention.

The third section of the text, "An American Romance," documents our love affair with these animals. It is filled with tales and lore passed on by those who have lived and worked among the bears, studied them for science, and hunted them for sport. Many of the stories are about firsthand encounters. A few of the chapters in this section are those dedicated to famous bears, hunting bears, camping with bears, and looking for bears. This section gives life to the complexity of these animals and our continued fascination with them.

The Bears of Yellowstone is a timeless, informative, and entertaining exploration of the black and grizzly bears of Yellowstone National Park. The text provides a diverse treatment of the subject by combining scientific data, political controversy, and historical perspective. The reader comes to better understand the natural history of these animals and the issues that have surrounded them since the establishment of Yellowstone National Park. With its unique historical perspective, the text nicely complements other texts dedicated to bears. Bear Attacks, Their Causes and Avoidance (The Lyons Press, 1985, 2002) by Steven Herrero offers more complete practical information for those who plan to spend time in bear country. Both volumes are worth reading for anyone interested in these animals. The Bears of Yellowstone should be required reading for anyone planning a visit to Yellowstone National Park.

David A. Townes, MD, MPH Seattle, WA, USA 